\title{
Influence of City Branding, Brand Identity, and Brand Image On Visiting Decision to Pekalongan City
}

\author{
UJIANTO PURWANTO, EUIS SOLIHA \\ ${ }^{1}$ Postgraduate Program, Faculty of Economic and Business, Universitas Stikubank, Semarang 50233, Indonesia \\ Email correspondence: uji97.indag@gmail.com, soliha.euis@gmail.com
}

\begin{abstract}
Recently, city branding has become the most crucial issue in tourism marketing. It is not only to attract the tourists to visit the city but also to improve its image. This research was conducted by respondent survey to analyze the influence of city branding to the decision for visiting Pekalongan city. Respondents were the visitors of mega event "Batik Pekalongan International Week." The respondents were the visitors of "Pekalongan Batik Week International." The research was conducted by using a survey design. Respondents were selected by purposive sampling in which they were adults of minimally senior high school graduates and employed. From the 125 surveyed respondents, 81 (64.8\%) were not Pekalongan people. Analysis methods of this study were multiple linear regression analysis, using $\mathrm{F}$ test, $\mathrm{t}$ test, and path analysis (mediation test). The result showed that city branding did not directly influence the decision to visit Pekalongan. City branding had effects on decision to visit Pekalongan through the mediation of brand identity and brand image.
\end{abstract}

Key words: City Branding, Brand Identity, Brand Image, The Decision to Visit.

\section{Pengaruh Branding Kota, Identitas Merek, dan Citra Merek Pada Keputusan Mungunjungi Kota Pekalongan}

\begin{abstract}
Abstrak
Baru-baru ini, branding kota telah menjadi isu yang paling penting dalam pemasaran pariwisata. Hal ini tidak hanya untuk menarik para wisatawan untuk mengunjungi kota tetapi juga untuk memperbaiki citranya. Penelitian ini dilakukan oleh survei responden untuk menganalisis pengaruh branding kota untuk keputusan untuk mengunjungi kota Pekalongan. Responden adalah para pengunjung acara besar "Batik Pekalongan Internasional Week." Responden adalah para pengunjung "Pekalongan Batik Week International." Penelitian ini dilakukan dengan menggunakan desain survei. Responden dipilih secara purposive sampling yang dimana mereka sudah dewasa minimal lulusan SMA dan bekerja. Dari 125 responden yang disurvei, 81 (64,8\%) bukan orang Pekalongan. Metode analisis penelitian ini adalah analisis regresi linier berganda, dengan uji $F$, uji $t$, dan analisis jalur (uji mediasi). Hasil penelitian menunjukkan bahwa merek kota tidak langsung mempengaruhi keputusan untuk mengunjungi Pekalongan. Branding Kota memiliki efek pada keputusan untuk mengunjungi Pekalongan melalui mediasi identitas merek dan citra merek.
\end{abstract}

Kata kunci: Branding Kota, Identitas Merek, Citra Merek, Keputusan Kunjungan. 


\section{INTRODUCTION}

Nowadays, city branding, nation branding, and regional branding are crucial issue in the world of marketing practices. Some countries in South-East Asia such as Malaysia, Hongkong, Singapura, and Tailand compete one another to promote the their countries as the best tourism destinations in Southeast Asia. Their taglines are "MalaysiaTrully Asia", "Unique Singapore", "Asia's World City!".They are not only to attract foreign tourists, but also to relieve their negative images.

Pekalongan, being aware of the city's potential in the field of batik, on April 1, 2011 to coincide with its 105th anniversary launched its branding tagline of Pekalongan with World's Batik City of Pekalongan. Branding was represented by a logo written as Pekalongan with a distinctive style, which describes the dynamics of the city's rich culture and traditions, including the warm and friendly people, topped with arches of flower stems depicting the growth of cities (Article 3 (1) of Pekalongan Mayor'sRegulation Number 30 Year 2011 on Branding Pekalongan).

Previous studies have been conducted in relation to city branding. City branding was found to be a broader concept than city marketing because it focuses on a holistic vision and cohesion between brand identity and brand image, while the city marketing is primarily associated with the fulfillment of the needs and expectations of customers (Krantz \& Schatzl, 1997). Thus the city branding would determine the brand identity that will ultimately change the image of the city (city image).

Research findings by Chaerani (2011) was related to the influence of city branding on the image of Solo city, namely the city branding had changed affective aspects, but it was unable to be used as a motivation to visit the city of Solo or to recommend Solo as a tourist destination and a place to stay. Jedras (2011) conducted on study on the impact of the creation of brand identity, and brand image of Milan as a city of fashion. From the study it could conclude that the image of Milan as a city of fashion among the respondents and identity of Milan as the city is not fully coherent with fashion, especially considering other cities in a comparison mode.
Hall (1992: 14) noted: "It is clear that the mega event which can have effects that form the image of the community or the host country, led to the perception of benefit as a potential tourist destination". This potential had been the reason for the event used as an additional tool of image, especially for large cities (Law, 1993; Holcomb, 1993; 1999; Sassen and Roost, 1999; Judd \& Fainstein, 1999; Selby, 2003).

Research findings about the impact of organizing events Vasconcelos Euro 2012 against the City of Warsaw imaging showed that the implementation of the Euro 2012 event had given the city a different image among tourists, businessmen, and locals. There were differences in the perception of the Warsaw between people closely associated with the city and people with little personal contact against Warsaw. It seemed clear that the image of Warsaw had not been well defined and able to be changed in the future. Their opinion on the appeal of the Warsaw travel was positive. However, among the citizens and entrepreneurs had unfavorable ratings above Warsaw. They are spatially united desires for future improvements of Warsaw.

Implementation of the Shanghai World Expo 2010 was considered successful, but had not been able to effectively fullfil the objectives of city branding, because it ignored the public recognition and sacrificing the interests of socially disadvantaged groups in the process of city branding (Wang, 2012). This event had not reflected the public participation inShanghai.

Gap was the main reason for carrying out a study to see the effectiveness of city branding and the mega event in influencing image as the world's Pekalongan batik city of which in turn influence the visiting decision to Kota Pekalongan.

The problems in this study are as follows: 1) Does the city branding influence on brand identity? 2) Does the city branding affect the brand image? 3) Does the brand identity affect the brand image? 4) Does the brand identity influence the decision been to Pekalongan? 5) Is the brand image influence the decision of a visit to the town of Pekalongan? 6) Does the city branding affect the decision to visit Pekalongan? 7) Does the city branding affect the 
decision been to Kota Pekalongan mediated by brand identity? 8) Does city branding influence the decision been to Kota Pekalongan mediated by brand image? 9) Does the city branding affect the brand image mediated by brand identity? and 10) Does the brand identity influence the decision to visit Kota Pekalongan mediated by brand image?

\section{LITERATUR REVIEW}

Purchasing decision is a problem solving process that consists of analyzing or recognition of the need and desire, information retrieval, assessment of the sources of the selection of alternative purchases, purchasing decisions and behavior after purchase (Kotler and Amstrong, 2004).

According to Kotler and Armstrong (2004) the starting point of purchase decision is the stimulus and response models of buying behavior. Marketing and other stimuli entered the "black box" of the consumer to generate a particular response. A marketer has to guess what is in the buyer's "black box".

Stimuli consist of the four P's of marketing, namely: product, price, place, and promotion. Other stimuli include strength and major events (mega event) within the buyer which include: economics, technology, politics, and culture. The whole of this feedback enters the black box buyer, and is converted into an arrangement of buyer feedback that can be investigated, namely: product choice, brand choice, the choice of dealer, time of purchase, and the purchase amount.

Brand image is the perception of the brand in the minds of the people, it is what people think about brands, their beliefs, expectations, emotions (Kavaratzis \& Ashworth, 2005). Brand identity is used to communicate the branded city. A city slogan and logo are part of the core concepts that are visible to the consumer (Anholt, 2007). Brand identity can be described as how stakeholders cities want the brand to be perceived by the consumer (Kavaratzis\& Ashworth, 2005). One of the important reasons is a unique brand identity in order to create a competitive advantage that will be recognized by consumers, meaning that consumers are aware of the city as they already have a basic knowledge of how the city (they have heard or read about the city).

As one of the brand identities, the conceptual logo ofcity has an impact on a successful city branding as strengthening brand equity through increased awareness, recognition, and royalties ofcustomers (Wheeler, 2009). A city logo helps to steer public perception and effectively revives a positive image for the city. Brand identity is the organization of the mega event. Hall (1992) stated that Mega event has become a particular form in which cultural value (currency of culture), especially in terms of their image effects.

Main marketing place and the most important success factor is the Planning group, Vision and Strategic Analysis, Place Identity and Image, PublicPrivate Partnerships and Leadership (Rainisto, 2003). In addition to the four (4) success factors above, to fullfil the challenges in an environment where the practice of place marketing is done, it is political unity (agreement on public affairs), Global Market, Regional Development and Process that coincidence (extraordinary event during the marketing process). A framework for evaluating city branding, called the city brand Hexagon, is used to make the Anholt-GMI City Brands Index (Anholt, 2006). The six components of the hexagon include the presence, place, potential, pulse, people and prerequisites.

Kavaratzis (2009) showed the frame of a city brand communication through different variables, which have both functional and symbolic meanings. This framework distinguishes between unintentional and intentional communication communication. Hankinson (2004) distinguishes four branding perspectives, namely; perception of the brand as an entity, as a brand communicator, Brand as a relationship, and brand as a major driver of value. Trueman and Cornelius (2006) suggested 'place brand toolkit', which includes five areas of action that can be taken, referred to as the 'Five Ps' place branding, namely: Presence, Purpose, Pace, Personality, and Power.

Kavaratzis (2009) described the similarity of concepts covering the main lessons of corporate branding and marketing theories. The similarity of the frames are grouped into eight (8) categories as a component of an integrated approach to managing city branding. 
JURNAL BISNIS \& MANAJEMEN

ISSN 1412 - 3681

These categories are: vision and strategy, internal culture, local communities, synergies, infrastructure, cityscape and gateways, opportunities, and communications.

Based on studies of experts, the researchers used the integration framework of city branding expressed by Kavaratzis (2009) to uncover the variables city branding in Pekalongan, which includes eight (8) dimensions: vision and strategy, internal culture, local communities, synergies, infrastructure, cityscape and gateways, opportunities, and communications.

Other previous studies include Jedras (2011) showing that the Image Milan as a city of fashion among the respondents and identity Milan as the city of fashion is not fully coherent, especially considering other cities for comparison mode. Vasconcelos (2012) showed that Euro 2012 event has given a different image the city among tourists, businessmen, and locals. Wang (2012) showed that the Shanghai World Expo 2010 event was considered successful in organizing the event, but had not been able to effectively meet the objectives of city branding. Wahyurini-Octavianty (2012) showed that the city Logo significantly influences city branding strategy. Chaerani (2011) showed that the city branding has changed affective aspects, but cannot motivate people to visit the city of Solo nor to recommend Solo as a tourist destination and a place to stay.

\section{Hypothesis}

According Kavaratzis and Ashworth (2005), branding strategy is concerned with aspects of brand identity, brand positioning and brand image. City branding strategy is communicated to the consumer by creating brand identity of the city, because basically brand identity is the way stakeholders want the city to be perceived by consumers.

\section{Hypothesis 1: city branding influences positively on brand identity.}

Simon Anholt in Moilanen and Rainisto (2009), defines city branding as management of image of a destination through strategic innovation as well as the coordination of economic, commercial, social, cultural, and government regulations. According Kavaratzis (2008), city branding is generally focused on the management of the image, exactly what and how that image will be formed as well as aspects of communications made in the management of process processing.

Hypothesis 2: city branding influences positively on brand image as the world's Pekalongan batik city in the eyes of consumers.

As one of the brand identity, conceptual city logo has an impact on a successful city branding as strengthening brand equity through increased awareness, recognition, and customers'royalties (Wheeler 2009, 11). A city logo helps to direct the perception (image) of the community and effectively revives a positive image to the city. Logo city that impact should be able to voice the city to stakeholders and help people become the property of the city.

Hypothesis 3: brand identity influences positively on brand image as the world's Pekalongan batik city in the eyes of consumers.

Logo city and the mega event as a component of brand identity would be "something" that is attractive to prospective customers. A football lovers will visit the show of World Cup even though he has never been to the host country. Likewise a fan batik batik will visit the event, although he has never been to the town organizers batik.

Hypothesis 4: brand identity influence positively on the decision to visit the city of Pekalongan.

A tourist destination can be viewed as a mixture of individual products and experiences that combine to form the total experience of the areas visited (Murphy in Ekinci, 2006). Previous studies have shown that the destination image has the cognitive and affective components (Kotler in Ekinci, 2006). Although the image destination that has been recognized as consisting of components affective and cognitive, previous studies have also shown a direct relationship between image destinations and trends of travelers recommended by word of mouth (Ekinci, 2006), and 
also a direct relationship between image destinations and expectations rating (Middleton, 2001).

Hypothesis 5: brand image of Pekalongan as the world of batik city influences positively on the decision to visit the city of Pekalongan.

City Branding will be a "something" that is attractive to prospective customers. City Branding is essentially a city promise to give something to the consumer. According to Kotler and Armstrong (2004) the starting point of purchase decision is a model of stimulus and response of consumer buying behavior. City branding can act as a stimulus for prospective customers so decided to visit the city.

Hypothesis 6: Hypothesis 6: city branding influence positively on the decision to visit the city of Pekalongan.

\section{RESEARCH METHOD}

The design study was survey design. Data needed in this study is the primary data by using questionnaires that had been prepared in which the respondent can choose the appropriate answers to perception (closed questions)This study employed Likert Scale with the size as follows: 1 = Strongly disagree. 2 = Disagree, 3 = Neutral, 4 = Agree, 5 = Strongly agree.

Purposive sampling method was used in the study, considering that visitors studied were adults, incomes and at least high school education. The sample population was the visitors of Pekalongan InternationalBatik Week.

Data analysis techniques for testing instruments, model testing, testing hypotheses and test mediation conducted by using Multivariate Analysis Applications with IBM SPSS 19 program.

Studied variables include the independent variables, city branding $(\mathrm{X})$, and the dependent variable was the decision been to Kota Pekalongan (Z), as well as two intervening variables that brand identity (Y1) and brand image (Y2). The developed model in the study were described in Picture1.

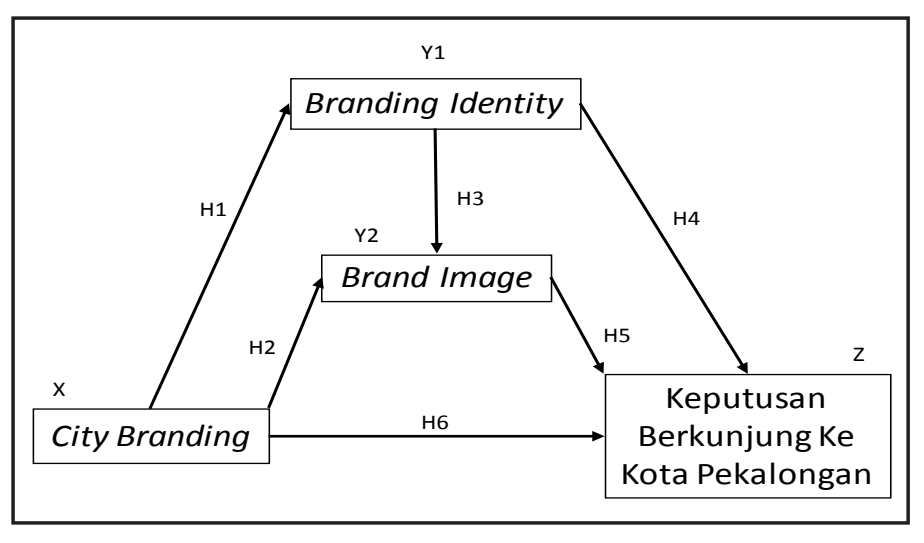

Picture 1 Empirical Research Model

\section{RESULTS AND DISCUSSION}

\section{Result}

Regression Equation

I. $\quad Y_{1}=a_{1}+\beta_{1} X+e_{1}$

II. $\quad Y_{2}=a_{2}+\beta_{2} X+\beta_{3} Y_{1}+e_{1}$

III. $Z=a_{3}+\beta_{6} X+\beta_{4} Y_{1}+\beta_{5} Y_{2}+e_{3}$

\section{Respondents' description}

Table 1 Responden By Origin Region

\begin{tabular}{lll}
\hline \multicolumn{1}{c}{ Origin Region } & Total & $\%$ \\
\hline Local Pekalongan & 44 & 35.2 \\
Central Java (except Pekalongan) & 35 & 28.0 \\
Java Island except Java Island & 32 & 25.6 \\
Outside Java Island & 14 & 11.2 \\
Total & $\mathbf{1 2 5}$ & $\mathbf{1 0 0 , 0}$ \\
\hline Source : Primary Data (2016) & &
\end{tabular}

Table 2 Respondents by Gender

\begin{tabular}{|c|c|c|}
\hline Gender & Total & $\%$ \\
\hline Male & 92 & 73,6 \\
\hline Female & 33 & 26,4 \\
\hline Total & 125 & 100,0 \\
\hline
\end{tabular}

Source : Primary Data (2016)

\section{Instrument Testing}

This study used a test instrument of test validity and reliability testing. Validity test was conducted using factor analysis. A questionnaire considered valid, if the questions on the questionnaire that would be capable of expressing a measured by the questionnaire. If the value of KMO above 0.5 then the sample was considered to have adequate levels of these samples. Limit the questionnaire considered 


\section{JURNAL BISNIS \& MANAJEMEN}

ISSN 1412 - 3681

valid if the loading factor of greater than 0.4 . If the Loading Factor (matrix component) value greater than 0.4 it is valid and deserves to be analyzed further. The results of the factor analysis showed all the indicators in this study is valid.

Reliability test in this study used Cronbach alpha value of 0.6 where a measuring instrument was declared more reliable if the results of the calculation of Cronbach alpha above 0.6. Reliability test results showed that the alpha value of the variable city branding, brand identity, brand image and the visiting decision above the figure of 0.6 or able to be concluded that all of the variables was reliable.

\section{Model Testing}

This study used a test of determination and Significance Simultaneous (Test Statistic F). Test of determination (adjusted $\mathrm{R}$ squared) included the ability of independent variables in explaining the dependent variable and the dependent variable proportion of the variation is explained by the variation of the independent variable. If the adjusted R2 obtained from the calculation results showed the greater (close to one), it could be infomed that the contribution of the independent variable on the dependent has a greater variation. This means that a larger model is used to explain the dependent variable. The statistical test $F$ basically indicates whether all the independent variables included in the model have influence together or simultaneously on the dependent variable (Ghozali, 2011). Model is declared fit if sig $\mathrm{F}$ value is less than 0.05 . The test results showed that all the models in this study fullfil the requirements in testing the model. Validity and Reliability Test were descibed in Table 3, and Model testing was described in Table 4.

Test Determination City Branding to Brand Identity obtained 0.499 Adjusted R Square of $49.9 \%$, changed from variable brand identity was able to be explained by the variables in the model city branding, while the remaining $50.1 \%$ was outside the model described above. Test Determination City Branding and Brand Identity Against Brand Image obtained Rsquare 0,556 Adjusted mean changed of $55.6 \%$ from the brand image of the variables could be explained by the variable city branding and brand identity in the model, while the remaining $44.4 \%$ is explained outside that model above. Test Determination of City Branding, Brand Identity and Brand Image against visiting decision to Pekalongan obtained Rsquare 0.716 , it wasa mean change of $71.6 \%$ from visiting decision variable to Kota Pekalonganwas able to be explained by the variable Pekalongan city branding, brand identity and brand image in the model, while

Table 3 Validity and Reliability Test

\begin{tabular}{|c|c|c|c|c|c|c|c|}
\hline \multicolumn{6}{|c|}{ Variable Validity Test (KMO >0,5 dan LF>0,4) } & \multicolumn{2}{|c|}{ Reliability Test (Alpha cronbach's $>0,6$ ) } \\
\hline & KMO & Result & Total Indicator & LF $>0,4$ & Result & Alpha Cronbach's & Result \\
\hline City Branding & 0,870 & Adequacy of sample & 23 & 23 & Valid & 0,920 & Reliable \\
\hline Brand Identity & 0,766 & Adequacy of sample & 4 & 4 & Valid & 0,801 & Reliable \\
\hline Brand Image & 0,884 & Adequacy of sample & 9 & 9 & Valid & 0,889 & Reliable \\
\hline Visiting decision & 0,928 & Adequacy of sample & 9 & 9 & Valid & 0,915 & Reliable \\
\hline
\end{tabular}

Source : Operated Primary Data (2016)

Table 4 Model Testing

\begin{tabular}{|c|c|c|c|c|}
\hline Model & Adjusted R Square & $\mathbf{F}$ & Sig & Decision Making \\
\hline \multirow[t]{2}{*}{ Equation 1} & 0.499 & & & $\begin{array}{l}49.9 \% \text { changing of brand identity variablecan be described by city branding variable, the } \\
\text { remain of } 50.1 \% \text { is described outside the model }\end{array}$ \\
\hline & & 124.5 & $.000^{\mathrm{b}}$ & Model had fulfill the requirement of goodness of fit (Sig $0.000<0.05$ ) \\
\hline \multirow[t]{2}{*}{ Equation 2} & 0,556 & & & $\begin{array}{l}55.6 \% \text { changing of brand image variablecan be described by city branding and brad } \\
\text { identity variable, the remain of } 44.4 \% \text { is described outside the model }\end{array}$ \\
\hline & & 78,6 & $.000^{\mathrm{b}}$ & Model had fulfill the requirement of goodness of fit (Sig $0.000<0.05$ ) \\
\hline \multirow[t]{2}{*}{ Equation 3} & 0,716 & & & $\begin{array}{l}71.6 \% \text { changing of brand image variablecan be described by city branding, brand identity, } \\
\text { and brand image variable, the remain of } 28.4 \% \text { is described outside the model. }\end{array}$ \\
\hline & & 105,4 & $.000^{\mathrm{b}}$ & Model had fulfill the requirement of goodness of fit (Sig $0.000<0.05)$ \\
\hline
\end{tabular}


the remaining $28.4 \%$ was outside the model described above.

\section{Hypothesis Testing}

Hypothesis testing was conducted by t test at three regression equation. These statistical tests basically show how far the influence of the independent variables individually (partially) explain the variations in the dependent variable, or to determine the level of significance individually each independent variable on the dependent variable. Hypothesis test results were explained in Table 5.

\section{Table 5 Hipotesis Test}

\begin{tabular}{cllccc}
\hline Model & Independent & Dependent & Beta & Sig. & Conclusion \\
\hline Equation 1 & City Branding & Brand Identity & 0.709 & 0.000 & Accepted \\
Equation 2 & City Branding & Brand Image & 0.323 & 0.000 & Accepted \\
& Brand Identity & Brand Image & 0.486 & 0.000 & Accepted \\
Equation 3 & City Branding & Visiting Decision & 0.061 & 0.394 & Accepted \\
& Brand Identity & Visiting Decision & 0.256 & 0.001 & Accepted \\
& Brand Image & Visiting Decision & 0.602 & 0.000 & Rejected \\
\hline
\end{tabular}

\section{Mediation Testing}

Mediation testing was conducted by path analysis method, path coefficient based on SPSS calculation of equation 1, 2, and 3 as descibed in Figure 2

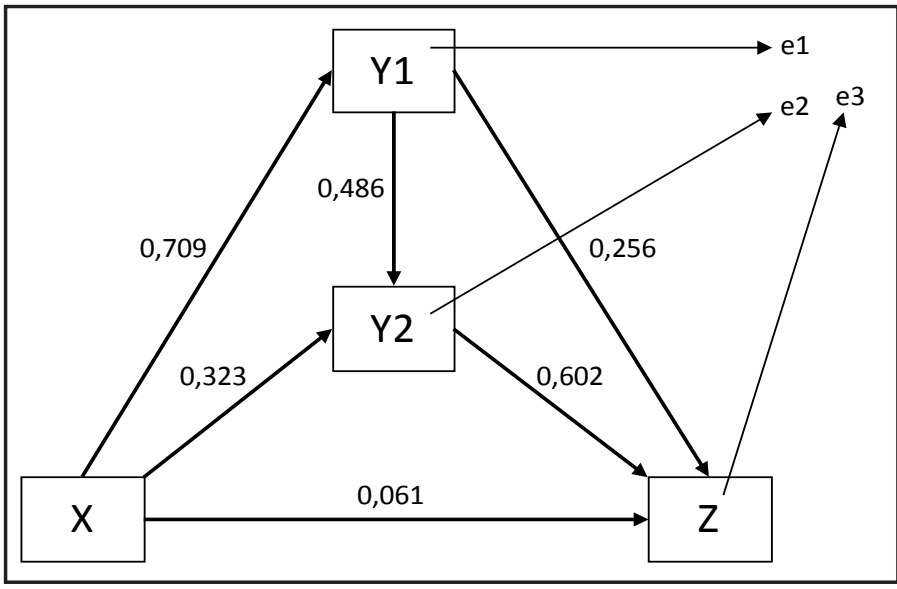

Figure 2 Path Coefficient

\section{Regression Equation}

$$
\begin{array}{ll}
\text { I. } & Y_{1}=a_{1}+\beta_{1} X+e_{1} \\
\text { II. } & Y_{2}=a_{2}+\beta_{2} X+\beta_{3} Y_{1}+e_{1} \\
\text { III. } & Z=a_{3}+\beta_{6} X+\beta_{4} Y_{1}+\beta_{5} Y_{2}+e_{3}
\end{array}
$$

Direct influence $X$ to $Z$ was 0.061 , while indirect influence $X$ to $Z$ with $Y 1$ mediation is $(0.709 \times 0.256)=$ 0.182 ; By $0.182>0.061$ value able to be concluded that full mediation (partially $X$ to $Z$ was not significantly influence) occured, or brand identity mediate the relation of city branding againt visiting decision.

Direct influence $X$ to $Z$ was 0.061 , while indirect influence $X$ to $Z$ with $Y 2$ mediation was $(0.323 x$ $0.602)=0.194$; By $0.194>0.061$ value able to be concluded that full mediation (partially $X$ to $Z$ was not significantly influence) occured, or brand image mediated the relation of city branding againt visiting decision.

Direct influence $X$ to $Y 2$ is 0.323 , while indirect influence $X$ to $Y 2$ with $Y 1$ mediation was $(0.709 x$ $0.486)=0.345$; By $0.345>0.323$ value able to conclude that mediation occured, or brand identity mediated the relation of city branding againtsbrand image.

Direct influence $\mathrm{Y} 1$ to $Z$ was of 0.256 , while indirect influence $Y 1$ to $Z$ with $Y 2$ mediationis $(0.486 \times 0.602)$ $=0.292$; by $0.292>0.256$ value can be concluded that mediation occured, or brand image mediated the relation brand identity againts visiting decisions.

\section{Discussion}

Result of hypothesis testing showed that the most dominant dimension to represent Pekalongan city branding was the dimension of vision and strategy with indicators vision and mission of the city, city branding law, as well as building a city branding strategy with an average score of respondents 4.40 . This suggests that in order to create a brand identity that can characterize Pekalongan as the "world's city of batik" required the creation of the vision, mission and strategies that better support for city branding. City branding influence on brand identity shows standardized beta value of 0.709 and 0.000 significance level of 0.05 , it would be concluded that the hypothesis city branding positively influence on brand identity is accepted.

The results are consistent with study of Kavaratzis \& Ashworth (2005), branding strategy concerning aspects of brand identity, brand positioning and brand image. City branding strategy is communicated to the consumer by creating brand identity of the city, 
JURNAL BISNIS \& MANAJEMEN

ISSN 1412 - 3681

because it is basically brand identity, that is an effort of town stakeholders who wants city branding able to be perceived by consumers.

The result of second hypothesis were able to show that in order to create a brand image which can provide insight to potential visitors about the city (cognitive), provide selection / comparison between the cities of other batik (evaluative) and eventually generate interest / inclination potential visitors to choose Pekalongan as a tourist destination (affective) required the creation of the vision, mission and strategies that better support for city branding.

Citybranding influence on brand image can be informed from the regression results indicate standardized beta values 0.323 and 0.000 significance level of less than 0.05 , it could be concluded that the hypothesis that city branding positively influence on brand image is accepted. The results are consistent with study of Simon Anholt in Moilanen \& Rainisto (2009), where Simon defined city branding as management of image of a destination through strategic innovation as well as the coordination of economic, commercial, social, cultural, and government regulations. This study is also consistent with study of Kavaratzis (2008) who argued that city branding is generally focused on the management of the image, exactly what and how that image will be formed as well as aspects of communications made in the management process image.

The third hypothesis test results showed that the most dominant dimension represents the brand identity is the dimension Pekalongan city logo with a score of 4.08 respondents. Therefore, this study concluded that in order to create a brand image which can provide insight to potential visitors about the city (cognitive), provide selection / comparison between the cities of other batik (evaluative) and eventually generate interest / inclination potential visitors to choose Pekalongan city as a tourist destination (affective) required the creation of a logo and tagline good city. Brand identity affect the brand image was able to be observed from the regression results indicate standardized beta values 0.486 and 0.000 significance level of less than 0.05 , it canbe concluded that the hypothesis brand identity positivelyinfluence on brand image is accepted. The results are consistent with research Wheeler (2009), that as a brand identity, logo conceptual city to have an impact in a successful city branding as strengthening brand equity through increased awareness, recognition, and 'customer royalty. A city logo helps to direct the perception (image) community and effectively revives a positive image to the city. Logo city that impact should be able to voice the city to stakeholders and help people become the property of the city. Therefore, it is necessary to develop the city logo as a design exercise in participatory, involving stakeholders and people in the design decisions. (Lau and Leung, 2010). Meanwhile, Mega event as one of the brand identity has been a certain form of cultural value (currency of culture), especially in terms of their image effects.

The fourth hypothesis test results showed that to encourage potential visitors decide to come to Kota Pekalongan required the creation of a logo and tagline good city. Brand identity influence the visiting decision to Kota Pekalongan can be seen from the regression results indicate standardized beta values of 0.256 and 0.001 significance level of less than 0.05 , it could be concluded that the hypothesis brand identity positive influence on the visiting decision to Kota Pekalongan received.

The results of this study were able to explain that the city and the mega event logo as a component of brand identity into a "something" that is attractive to prospective customers. A football lovers will visit the show Worl Cup even though he had never been to the host country. Likewise a fan batik will visit the event, although he has never been to the town organizers of batik.

The fifth hypothesis test results showed that the most dominant dimension represents the brand image Pekalongan is a cognitive dimension to the seriousness indicator Pekalongan city government in the publication, introduction of the logo, and recognize Pekalongan batik as the largest city in Indonesia with an average score of respondents 3.95. Therefore, this study concludes that in order to encourage potential visitors decide to come to Pekalongan City necessary knowledge about the city (cognitive).

Brand image influence the visiting decision to Pekalongan City we able be seen from the regression 
by the brand identity directly. This means that by the better implementation of city branding which mediated by brand identity in the form of the logo of the city and the implementation of the mega event will encourage potential visitors to come to the city of Pekalongan.

Ekinci (2006). A tourist destination was viewed as a mixture of individual products and experiences that combine to form the total experience of the areas visited. Previous study had shown that the destination image has the cognitive and affective components (Kotler in Ekinci, 2006). Although the image destination had been recognized consists of components affective and cognitive, previous studies have also shown a direct relationship between image destinations and trends of travelers recommend word of mouth (word of mouth) (Ekinci, 2006), and also a direct relationship between image destinations and expectations traveler. A study by Ekinci (2006) shows it important in making and observing the personality of the destination to reposition and differentiate it in the travel market. This can be done through a whole series of publicity and marketing techniques, including imaging (Ekinci, 2006).

The sixth hypothesis test results showed that city branding has no direct influence over the decision to visit the city of Pekalongan. However, based on the test mediation appears that city branding will influence the decision been if there efforts to characterize the city (brand identity) that will cause the city's image (brand image). Finally, a good image will encourage prospective visitors decided to come to the city of Pekalongan. City Branding influence the decision been to Pekalongan City could be known from the regression results indicate standardized beta values 0.061 and 0.394 significance level greater than 0.05 , it can be concluded that partial hypothesis city branding influences affect the decision been to Pekalongan City acceptable.

In relation to the significant influence of city branding on the visiting decision to Pekalongan City will be described in the discussion of mediation brand identity and brand image.

Influence of City Branding on visiting decision mediated by Brand Identity

Result study of city branding influence on visiting decision to Pekalongan City more effective if mediated

The mediation was full mediation. It can be explained that there is no direct influence city branding to the visiting decision. However, with the mediation of the city branding so brand identity will influence indirectly to the visiting decision to Pekalongan.

\section{Influence City Branding on Brand Image mediated by Brand Identity}

Result study of the influence city branding on brand image is more effective if mediated by brand identity than directly. It means the better implementation of city branding which mediatied of brand identity performing (such a city logo creation and event organizing) so would enhance brand image Pekalongan City on visitors mind.

\section{Influence of Brand identity on visiting decision} mediated by brand image

Result study of the influence brand identity on visiting decision to Pekalongan City is more effective if mediated by brand image than directly. It means the better implementation of brand identity (such a city logo creation and event organizing) and by mediating the high brand image on visitors mind, it would encourage them to visit Pekalongan City.

\section{CONCLUSION AND RECOMMENDATION}

\section{Conclusion}

From the results of the discussion about relationship among variables, it can be concluded that the city branding significantly influences on brand identity, city branding significantly influence on brand image, brand identity significantly influence on brand image, brand identity significantly influence on visiting decisions been to Pekalongan City, brand image significantly influence on the visiting decision to Pekalongan City but city branding did not not influence the visiting decision to Pekalongan City.

This study was able to explain that although city branding did not directly influence on the visiting decision, but by mediation of brand identity and 
JURNAL BISNIS \& MANAJEMEN

ISSN 1412 - 3681

brand image, city branding would give significant impact on the visiting decision Pekalongan City. In other words, the optimization of the implementation of city branding would have an influence on the characterization of the city (identity) thus it will be understood (cognitive), selected (evaluative), and appealing (affective) for potential visitors, which in turn prospective visitors decided to come to Pekalongan City.

\section{Recommendation}

This study provides a theoretical and practical implications. Theoretically, this study contributes to the development of the theory of public marketing, in this case the city branding, brand identity, brand image and purchasing decisions related to tourism. The contributions is an understanding that in order to encourage potential visitors decide to come to a tourist destination required the creation of the city's identity (brand identity) that will eventually lead to the image (brand image) of the city. Overall the results of this study, in addition to supporting the theory that had been there before but also support in determining managerial policy. The implementation of managerial suggested by this study are as follows:

From the study oncity branding variable of Kota Pekalongan showed that the website http:// pekalongankota.go.id has not been capable to optimally sell Pekalongan via the Internet. The dimensions of communication in city branding needs to be effectively improved.

From the study on brand identity variable it was known that the event Pekalongan International Batik Week was unable to be characterized as the world city of batik in this area. Therefore, Pekalongan Government's efforts in giving the perception / image of the world city of batik in the performance event still needed improving.

From the results of study on brand image variables, it can be informed that when compared to Yogyakarta and Solo, Pekalongan does not have the infrastructural culture and more attractive and unique batik tourism. This relates to the evaluative dimension in the formation of city image in the minds of visitors, meaning that the image of visitors were still more inclined to Yogyakarta or Solo in terms of infrastructural culture and batik tourism. Therefore it is necessary to be deal with unique infrastructural components of batik with world class standard.

From the results of study on visiting decision variables to Pekalongan City it was known that visitors decided to visit the Pekalongan International Batik Week not because of the event though designed more spectacularly as compared to Yogyakarta and Solo. This means that event "Pekalongan International Batik Week" has not been able to position itself as a great and spectacular event. Therefore it is necessary to improve the event of Pekalongan International Batik Week to be more and more spectacular with a world-class standard.

Brand identity which was raised in this study is the logo of the city and the organization of Pekalongan International Batik Week. It could not represent the brand identity of Pekalongan City as a whole. One component of brand identity which has not been discussed is Setono Wholesale Market, a landmark on the welcome monument, Museum Batik, Kampoeng Batik, and so forth. Brand Identity that has not been dealt with can later be further investigated

This study used a survey by distributing questionnaires which could not reveal the deeper reasons that people visit Kota Pekalongan. It is recommended that future researches be supplemented with in-depth interviews.

\section{REFERENCE}

Anholt S, (2006). The Anholt-Gmi City Brands Index: How The World Sees The World's Cities. Place Branding, 2(1): 18-31.

Anholt S, (2007). Competitive Identity: The New Brand Management for Nations. London: Palgrave.

Chaerani, (2011). Pengaruh City Branding terhadap City Image (Studi Pencitraan Kota Solo: 'The Spirit of Java'). Solo, Indonesia: Universitas Sultan Ageng Tirtayasa Press.

Ekinci Y, (2006). "Destination Personality: An Apllication of Brand Personality to Tourism 
Destination". Journal of Travel Research, 45(2), 127-139.

Ghozali, I, (2011). Aplikasi Analisis Multivariate dengan Program IBM SPSS 19. Semarang, Indonesia: Universitas Diponegoro Press.

Hall, C. M, (1992). Hallmark Tourist Events. London: Belhaven Press.

Hankinson, G, (2004). "Relational Network Brands: Towards A Conceptual Model of Place Brands". Journal of Vacation Marketing, 10(2): 109-121.

Holcomb, B. (1993). Revisioning Place: De- And Reconstructing The Image Of The Industrial City. in: G. Kearns and C. Philo (Eds) Selling Places, pp. 133-143. Oxford: Pergamon Press.

Holcomb, B. (1999). Marketing Cities For Tourism. in: D. R. Judd and S. Fainstein (Eds) The Tourist City, pp. 54-70. New Haven, CT: Yale University Press.

Jedras, (2011). City Branding The Perception Of Milan As A World Fashion Capital. Rotterdam, Netherland: Erasmus University Press.

Judd, D. R. and Fainstein, S. (Eds) (1999). The Tourist City. New Haven, CT: Yale University Press.

Kavaratzis M, and G. J.Ashworth, (2005). "CityBranding: An Effective Assertion of Identity or A Transitory Marketing Trick". Journal of Place Branding, 2(3), 183-194.

Kavaratzis, M, (2008). From City Marketing To City Branding, An Interdisciplinary Analysis With Reference To Amsterdam, Budapest And Athens. Groningen, Netherland: University of Groningen Press.

Kavaratzis, M, (2009). "Cities and Their Brands: Lessons from Corporate Branding". Place branding and public diplomacy, 5(1), 26-37.

Kavaratzis, M, (2010). Branding The City Through
Culture And Entertainment. Groningen, Netherland: University of Groningen Press.

Kotler, P., and G. Armstrong, (2004). Principles of Marketing. Tenth Ed. New Jersey : Pearson Prentice Hall.

Krantz, M and Schatzl, L (1997). Marketing The City. In: European Cities in Competition (eds), Jensen- Butler,C., Shachar, A., Weesep, J. (eds) 1997. Avebury: Ashgate Publishing Company.

Lau, F. and A. Leung, (2010). Chongqing's City Branding: The Role of Graphic Design. In City Branding: Theory and Cases, ed. D. K. Dinnie, 131-137. Palgrave Macmillan, Ltd.

Law, C. (1993). Urban Tourism: Attracting Visitors to Major Cities. London: Mansell.

Middleton V. (2001). Marketing in Travel and Tourism. 3rd Edition, Oxford: ButterworthHeinemann.

Moilanen, T., S. Rainisto, (2009). How to Brand Nations, Cities and Destinations. A Planning Book for Place Branding. Palgrave Mamillan.

Rainisto, S. K, (2003). Success Factors of Place Marketing: A Study of Place Marketing Practices in Northern Europe and The United States. Helsinki, Finland :Helsinki University of Technology.

Sassen, S. and Roost, F. (1999). The City: Strategic Site For The Global Entertainment Industry. In: D. R. Judd and S. Fainstein (Eds) The Tourist City, pp. 143-154. New Haven, CT: Yale University Press.

Selby, M. (2003). Understanding Urban Tourism: Image, Culture and Experience. London: I. B. Tauris.

Trueman, M. and Cornelius, N. (2006). Hanging Baskets Or Basket Cases? Managing The Complexity Of City Brands And Regeneration. Working Paper 06/13, Bradford University 


\section{JURNAL BISNIS \& MANAJEMEN}

ISSN 1412 - 3681

School of Management, Bradford.

Vasconcelos. (2012). The Effects of Mega-Events on City Branding - The Example of Warsaw And Euro 2012. Warsawa, Poland: Warsawa School of Economics Press.

Wahyurini-Octavianty (2012). The Significance of City Logo in City Branding Strategy. Recent Researches In Engineering Mechanics, Urban and Naval Transportation And
Jurnal Bisnis \& Manajemen, 2017, Vol. XVIII, No. 1, 34-45

Tourism; (EMESEG '12).

Wang, (2012). "Mega-Events and City Branding: A Case Study of Shanghai World Expo 2010". Journal of US-China Public Administration, 9 (11), 1283-1293.

Wheeler A, (2009). Designing Brand Identity. New Jersey: John Wiley and Sons, Inc. 